\title{
Assessing economic development through trade relations and educational markets integration (the case of Vietnam within ACFTA)
}

\author{
Thinh Bui Tien ${ }^{1, *}$, Hung Tran $\operatorname{Van}^{2}$ \\ ${ }^{1}$ Ho Chi Minh University of Technology and Education, Ho Chi Minh City, Vietnam \\ ${ }^{2}$ Vietnam National University of Forestry, Dong Nai Province, Vietnam
}

\begin{abstract}
This paper applies the gravity model of trade with panel database to assess the impact of ACFTA on the export and import of ACFTA's members from 2001 to 2018. The database was taken from World Bank Database, International Trade Center andCEPII Research and Expertise on The World Economy. The estimation results review that ACFTA has positive trade creation and trade diversion effect on the export of all ACFTA's members including Vietnam, ACFTA does play a pivotal role in the intra - regional export and extra - regional export of Vietnam and other ACFTA's members. Furthermore, within the scope of the paper, compared to other FTA of ASEAN, the magnitude of trade creation of ACFTA is considerably large. This is consistent with the fact that China is gradually becoming a fundamental trade partner with ASEAN and Vietnam in particular. Contrary to the positive effect of ACFTA on members'export,the estimation results show that ACFTA is causing negative trade diversion effect on the import of ASEAN members within ACFTA including Vietnam. This is in line with the fact that ASEAN and Vietnam in particular have been running trade deficit with China since 2010 at the expense of import from other trading partners, and the trade deficit has been increasingsince ACFTA came into full effect.
\end{abstract}

\section{Introduction}

Since the Communist Party of Vietnam and the Vietnamese Government began the Renovation Policy in 1986 with the goal of changing the then Vietnam's command economy to a socialist - orientation market economy, Vietnam has been focusing on and participating in the global and regional economic intergration. In particular, the regional economic integration through various billateral trade agreements with ASEAN and East Asia countries including China has become one of the primary focuses of Vietnamese Government. With the gradual development of economic relationship between China and ASEAN's members in 1990s, in 2001 China and ASEAN's members together established the ASEAN - China Free Trade Area (ACFTA) with the goal of maintaining and developing the economic relationship and regional cooperation as well as bilateral trade relationship in particular between China and ASEAN's members [1].

\footnotetext{
* Corresponding author: thinhbt@homute.edu.vn
} 
Although ACFTA offers its members many opportunities to develop bilateral trade and - investment relationship through the process of trade and investment liberalization, Vietnam and other ASEAN members still face many challenges, especially with the increasing trade deficit ASEAN has been running with China within ACFTA since 2010. In fact, Vietnam is one of the four ASEAN's members which have had the largest trade deficitwith China since ACFTA came into full effect, and the trend of increasing trade deficit over the years has raised concernsabout the negative impacts of ACFTA on Vietnamese trade [2]. In addition, following the process of ACFTA, all members completed the reduction and elimination of tariffs in 2015, which also increases the risk of the ASEAN's and Vietnam's market to become "backyards" consumption of Chinese goods, followed by long - term negative impacts on the economies of ASEAN members within ACFTA. As such, this study aims to assess the situation of Vietnam's economic integration under ACFTA through trade [3]. More specifically, the authors of the paper will assess the impacts of ACFTA on Vietnam's trade in goods within ACFTA and Vietnam's trade in goods with Vietnam's top trading partners in order to propose recommendations to improve the efficiency of Vietnam's regioanl economic integration under ACFTA.

\section{Definition of international trade and international economic integration}

According to [4] international trade is the process of exchanging goods and services between countries through trading activities in order to maximize profits. Furthermore, international trade plays an important role as it helps developing economies in general and enhancing the process of regional and internationaleconomic integration process in particular.

According to $[5,6]$ economic integration is a process that creates economic relationship between countries, including the elimicountry of goods and services discrimicountry through the removal of tariff and non - tariff barriers.

Additionally, [4] conceptualizes economic integration as an economic relation that goes beyond any country's territorial border. Economic integration process begins as countries start developing and enhancing their trade relation with each other and with the rest of the world, as well as other economics activities based on regional - level or international level agreements.

To sum up, international trade is the process of trading goods and services between countries. A country's trade value with its trading partner is a pivotal indicator of the country's level of regional and international economic integration.

\section{Methodology: Data and the gravity model of trade}

The authors' paper built a panel databasewith export - import value, GDP and and GDP per capita, population, geographical distance, common borders and languages of 17 countries including: 10 members of ASEAN, China, Japan, Korea, Australia, New Zealand, India and Hong Kong between 2001 and 2018. In addition to ACFTA members, other countries are selected because: The aforementionedcountries are all important trading partners of Vietnam, furthermore, they have already established free trade agreements with Vietnam and ASEAN. From the estimation result, the authors will compare the impact of trade creation effect between ACFTA and other free trade agreements.

The total number of observations in the database is 4896 ( 17 countries, 16 pairs and 18 years). China, Japan, Korea, Australia, New Zealand and Hong Kong are all major importers of Vietnam's goods and all have signed FTAs with ASEAN. However, Hong 
Kong is an exception because the ASEAN - Hong Kong Free Trade Agreement will come into full effect in 2020, so the impact of ASEAN - Hong Kong Free Trade Agreement is outside the scope of the paper.

The gravity model of trade used in this paperis based on the gravity model of trade that [7] used to analyze the impact of ASEAN - Korea Free Trade Agreement on trade value between Vietnam and Korea in the $2001-2009$ periods.

In addition to the explanatory variables such as GDP and GDP per capita, FTA dummy variables, the authors added three new dummy variables: Common borders, common languages and a dummy variable representing the effect of trade diversion.

The gravity model of trade is built for export and import to evaluate the impact of Vietnam's economic integration statuswithinACFTA through trade liberation as follows:

The gravity model of trade for export value:

$$
\begin{gathered}
\log (\text { EXijt })=\alpha+\beta 1 \log (\text { GDP_EXPit })+\beta 2 \log (\text { GDP_IMPjt })+\beta 3 \log (\text { GDPPC_GAPij })+ \\
\beta 4 \log (\text { POP_EXPit })+\beta 5 \log (\text { POP_IMPjt })+\beta 6 \log (\text { DISTWij })+\beta \text { BORDERij }+ \\
\beta 8 \text { LANGUAGEij }+\beta 9 \text { ACFTA }+\beta 10 \text { AANZFTA }+\beta 11 \text { AIFTA }+\beta 12 \text { AJCEP }++ \\
\beta 13 \text { AKFTA }+\beta 14 \text { ACFTA_ } 2+\varepsilon(1)
\end{gathered}
$$

The gravity model of trade for import value:

$$
\begin{gathered}
\log (\text { IMijt })=\alpha+\beta 1 \log (\text { GDP_EXPit })+\beta 2 \log (\text { GDP_IMPjt })+\beta 3 \log (\text { GDPPC_GAPij })+ \\
\beta 4 \log (\text { POP_EXPit })+\beta 5 \log (\text { POP_IMPjt })+\beta 6 \log (\text { DISTWij })+\beta 7 \text { BORDERij }+ \\
\beta 8 \text { LANGUAGEij }+\beta 9 \text { ACFTA }+\beta 10 \text { AANZFTA }+\beta 11 \text { AIFTA }+\beta 12 \text { AJCEP }++ \\
\beta 13 \text { AKFTA }+\beta 14 \text { ACFTA_ } 2+\varepsilon(2)
\end{gathered}
$$

The explanatory variables are as follow:

Country $\mathrm{i}$ and country $\mathrm{j}$ : The exporting and importing countries.

EXijt và IMijt: The export and import value of country $i$ to country $j$ in time $t$.

GDP_EXPit và GDP_IMPjt: GDP of country iand jin time t.

GDPPC_GAPijt: The difference of GDP per capita between countryi and countryj in time $t$, this explanatory variable is to verify the assumption of the Linder effect, in which countries with similar GDP per capitawill tend totrade with each other more than tradingwith othercountries with significant disparities in GDP per capita. If the GDPPC GAP variable is negative, this is a sign of the Linder effect. In contrast, GDPPC_GAP with positive sign will fit with the hypothesis of Hecker - Ohlin model.

POP_EXPit và POP_IMPjt: Total population of country $i$ and country $j$ in time $t$.

DISTWij: Geographical distances between country i and country $j$.

BORDERij và LANGUAGEij: These dummy variable will take the value of 1 if country $i$ and country $j$ do share geographical border and languages, and 0 otherwise.

The following dummy variables: ACFTA, AKFTA, AANZFTA, AIFTA and AJCEP represent the FTAs and their trade creation effect. These dummy variables will take the value of 1 if both countries are members of the same FTA and from the time that these free trade agreements came into effect for goods trading, and 0 otherwise.

The above FTA dummy variables' coefficients also indicate the effect of trade creation of FTAs. If the coefficient of a FTA dummy variable is positive, the result can be intepreted that joining the FTA will help increase trade valueof all members. In constrast, if the coefficient is negative, this result indicates that joining the FTA may negatively affect a member's trade value with other members within aforementoned FTA.

ACFTA_2: This dummy variable will take the value of 1 if country $i$ is a member of ACFTA and country $\mathrm{j}$ is not a member of ACFTA. The dummy variable ACFTA_2 represents the trade diversion effect of ACFTA to member countries. Accordingly, if the coefficient of ACFTA_2 is positive, the results demonstrate that joining ACFTA will also promote ACFTA member countries to increase trade value with countries outside of 
ACFTA and indicate a positive trade diversion effect. Otherwise, if the coefficient is negative, the result indicates a negative trade diversion effect for FTA's members as the intra - regional trade value may increase at the expense of trade value with countries outside FTA [8].

In the scope of the paper, the hypothesis is as follow:

$\mathrm{H} 0: \beta 1=\beta 2=\beta 3=\beta 4=\beta 5=\beta 6=\beta 7=\beta 8=\beta 9=\beta 10=\beta 10=\beta 11=\beta 12=\beta 13=\beta 14$ $=0$, all of the explanatory variables are statistically insignificant.

$\mathrm{H} 1 \neq \mathrm{H} 0$, the explanatory variables are statistically significant.

\section{Estimation results and discussion}

\subsection{ACFTA impacts on export value of Vietnam and other ACFTA's members}

The estimation results of coefficients, variance and statistical level of significance of explanatory variables from the gravity model of trade of export between countries based on three estimation methods: OLS, Fixed Effect Model and Random Effect Model is shown as follows:

The results of the Breusch-Pagan Lagrange test and the Hausman test allow to confirm the fitness of the Fixed Effect Model. From this point forward, the fixed effect model will be used in the paper to analyze the impact of ACFTA on Vietnam's export trade.

In general, the $\mathrm{R}$ - squared value is 0.6779 indicating that about $67.8 \%$ of the export value of the countries are explained by the gravity model of trade. The estimation results show that most explanatory variables are statistically significant and have expected signs with the exception of GDPPC_DIF and AIFTA. This illustrates that the impact of AIFTA on ASEAN trade in general and Vietnam in particular is not significant. The variables GDP_EXP and GDP_IMP are positive and statistically significant at 1\% confidence level. This result is consistent with the hypothesis of the gravity model of trade: GDP indicates the size of the economy, the larger the economy the higher the tradevalue, and this is also consistent with the reality of Vietnam, within the scope of the paper, that the greater the GDP of Vietnam, the higher the tradevalue between Vietnam and other Vietnam's important trading partners. In exporting countries, a 1\% increase in GDP and other explanatory variables will increase the export value of goods to $0.67 \%$, similarly, if the GDP of the importing countries increases by $1 \%$, the export value will increase by $1.75 \%$.

Both of the explanatory variables POP_EXP and POP_IMP are statistically significant at $1 \%$ level of confidence. This result demonstrates that the effect of domestic production and consumption is greater than the effect of economies of scale, and countries with large populations tend to produce and consumer goods domestically and are less dependent on international commerce. It is worth noting that the explanatory variable POP_EXP has a large coefficient compared to POP_IMP. This suggests that populous countries like China and India will tend to produce and consumer goods more than they import, which could cause an adverse impact on the export of other countries to these populous countries.

The explanatory variable DISTW has a negative sign and is statistically significant at $1 \%$ level of confidence, this result is consistent with the hypothesis of the gravity model of trade on the impact of geographical distance on countries' trade. The greater the geographical distance between the two countries, the higher the cost of trade between the countries, leading to trade restrictions between the two countries. In constrast, the explanatory variables BORDER (countryal borders) and LANGUAGE (common languages) are statistically significant at $1 \%$ confidence level and are positive signs showing that countries sharing the same border and language tend to. trade more with each other. 
Table 1. Coefficients, variance and statistical level of significance of explanatory variables from the estimation result of equation (1). Estimation methods: OLS, FEM and REM.



For FTA dummy variables, except for two variables: AIFTA is not statistically significant indicating that the impact of this variable on ASEAN and Vietnam in particular is not significant, and AKFTA has negative sign although it is statistically significant at $1 \%$ confidence level, the remaining FTA variables are positive and statistically significant.

In terms of ACFTA, its coefficient is quite large compared to AANZFTA, AIFTA and only second to AJCEP, this result shows that ACFTA has created a positive trade creation effect that boosts the export value of intra-regional export trade for ACFTA's members. As the coefficient of ACFTA is second only to the coefficient of AJCEP, this reviews that, in the scope of the study, the effect of ACFTA on trade creation is very large. In the 2005 2018 period, ASEAN's export to China increased from 104.51 billion USD in 2005 to 397.91 billion USD in 2018, China also exported goods to ASEAN with the corresponding value, from 55.31 billion USD in. 2005 to 320.66 billion USD in 2018. In the three years of 2016, 2017 and 2018, ASEAN increased the export value of goods to China, while the export value of Chinese goods decreased. The authors of the thesis commented that factors of economic size and natural resources of China and ASEAN plays an important role in 
promoting intra-group export process of the members. In addition, China has been heavily impacted by the trade war with the United States since 2016, the US - China Trade War has contributed to prompting China to seek new trading partners to compensate for the damage from the trade warwith the United States. This is also consistent with the fact that China is gradually becoming one of the five largest trading partners of ASEAN in general and Vietnam in particular since 2010.

In addition, the variable ACFTA_2 has a positive sign and is statistically significant at $1 \%$, additionally its coefficient value is relatively large $(0.8816)$ and nearly equal to the coefficient of ACFTA. This indicates that ACFTA's trade diversion effect on members is positive. In other words, the increase in ACFTA's intra-trade export value does not reduce ASEAN's export trade to countries outside ACFTA. This is a positive sign for Vietnam and other ASEAN's members, showing that the process of seeking and diversifying trade relations with other countries has been positive. By 2018, within ACFTA, both ASEAN and China maintained good trade value with the rest of the world, as shown by the proportion of trade with the rest of the world of both China, ASEAN and Vietnam at over $80 \%$.

\subsection{ACFTA impacts on import value of Vietnam and other ACFTA's members}

The estimation result of coefficients, variance and statistical level of significance of explanatory variables from the gravity model of trade of export between countries based on three estimation methods: OLS, Fixed Effect Model and Random Effect Model is shown as follows:

The results of the Breusch-Pagan Lagrange test and the Hausman test allow the confirm the fitness of the Fixed Effect Model. From this point forward, the fixed effect model will be used in the paper to analyze the impact of ACFTA on Vietnam's import trade.

In general, the $\mathrm{R}$ - squared value is 0.7715 indicating that about $77 \%$ of the import value of the countries is explained by the gravity model of trade. Similar to the estimation results of the gravity model of trade for export, the estimation results show that most explanatory variables are statistically significant and have expected signs except for AANZFTA and AIFTA, the extent of the impact of AANZFTA and AIFTA on import value of ASEAN and Vietnam in particular is not significant. Additionally, the explanatory variables GDP of exporting and importing countries have a positive coefficient and are statistically significant at the $1 \%$ level of confidence $[9,10]$.

This result is consistent with the hypothesis of the trade model: GDP shows the size of the economy, the larger the economy has the higher trade, and this result is also consistent with the reality of Vietnam [11]. 1\% increase in GDP and other explanatory variables would increase the export value of goods to $1.4427 \%$, similarly, when the $1 \%$ GDP increase of the importing countries will increase the price. import value up to $0.3903 \%$.

Contrary to the estimation results of the gravity model of trade for export, the explanatory variable GDP_DIF is negative and statistically significant at $1 \%$ level. The result indicatesthe impacts of Linder effect.Within ACFTA, China and many other ASEAN'smembers have similar GDP per capita such as Thailand, Indonesia, and Vietnam tend to trade more with each other. However, the impact of GDP DIF is quite small compared to GDP_EXP and GDP_IMP. When the other explanatory variables remain the same and the GDP DIF variable increases by $1 \%$, this only leads to a change of about $0.0557 \%$ of the import trade value of the countries in the study. 
Table 2. Coefficients, variance and statistical level of significance of explanatory variables from the estimation result of equation (1). Estimation methods: OLS, FEM and REM.

\begin{tabular}{|c|c|c|c|}
\hline $\begin{array}{c}\text { Explanatory } \\
\text { variables }\end{array}$ & OLS & Fixed & Random \\
\hline GDP_EXP & $\begin{array}{c}1.3179 * * * \\
(0.0206)\end{array}$ & $\begin{array}{c}1.4427 * * * \\
(0.0192)\end{array}$ & $\begin{array}{c}0.8450 * * * \\
(0.0340)\end{array}$ \\
\hline GDP_IMP & $\begin{array}{c}0.8554 * * * \\
(0.0230)\end{array}$ & $\begin{array}{c}0.3903 * * * \\
(0.0959)\end{array}$ & $\begin{array}{c}0.6145^{* * * *} \\
(0.0383)\end{array}$ \\
\hline GDPPC_DIF & $\begin{array}{c}-0.0576^{* *} \\
(0.0203)\end{array}$ & $\begin{array}{c}-0.0557 * * * \\
(0.0179)\end{array}$ & $\begin{array}{c}0.0027 \\
(0.0250)\end{array}$ \\
\hline POP_EXP & $\begin{array}{c}-0.2389^{* * *} \\
(0.0198)\end{array}$ & $\begin{array}{c}-0.3202 * * * \\
(0.0178)\end{array}$ & $\begin{array}{c}0.0337 \\
(0.0576)\end{array}$ \\
\hline POP_IMP & $\begin{array}{c}0.0261^{* * * *} \\
(0.0206)\end{array}$ & $\begin{array}{c}-3.6314^{* * * *} \\
(0.6833)\end{array}$ & $\begin{array}{l}0.1092^{*} \\
(0.0590) \\
\end{array}$ \\
\hline DISTW & $\begin{array}{c}-1.0621 * * * \\
(0.0475) \\
\end{array}$ & $\begin{array}{c}-0.8223 * * * \\
(0.0481)\end{array}$ & $\begin{array}{l}-0.0078 \\
(0.0499) \\
\end{array}$ \\
\hline BORDER & $\begin{array}{c}0.6312^{* * * *} \\
(0.0931)\end{array}$ & $\begin{array}{c}0.8688 * * * \\
(0.0851)\end{array}$ & $\begin{array}{c}0.9998 * * * \\
(0.3173) \\
\end{array}$ \\
\hline LANGUAGE & $\begin{array}{c}0.7305^{* * * *} \\
(.0744)\end{array}$ & $\begin{array}{c}0.4394 * * * \\
(0.0725) \\
\end{array}$ & $\begin{array}{l}1.045 * * * \\
(0.2855)\end{array}$ \\
\hline AJCEP & $\begin{array}{c}-0.1199 \\
0.0986 \\
\end{array}$ & $\begin{array}{l}-0.1521^{*} \\
(0.0935) \\
\end{array}$ & $\begin{array}{l}-0.1432^{*} \\
(0.0613) \\
\end{array}$ \\
\hline AANZFTA & $\begin{array}{l}-0.0468 \\
(0.0906)\end{array}$ & $\begin{array}{c}0.0295 \\
(0.0857)\end{array}$ & $\begin{array}{c}-0.3598 * * * \\
(0.0512)\end{array}$ \\
\hline AIFTA & $\begin{array}{c}-0.7084 * * * \\
(0.1074)\end{array}$ & $\begin{array}{c}0.0705 \\
(0.0101)\end{array}$ & $\begin{array}{c}0.2915 * * * \\
(0.0596)\end{array}$ \\
\hline AKFTA & $\begin{array}{l}0.6590 * * * \\
(0.09693)\end{array}$ & $\begin{array}{c}0.6458 * * * \\
(0.0938)\end{array}$ & $\begin{array}{c}0.0986 \\
(0.0644)\end{array}$ \\
\hline ACFTA & $\begin{array}{c}-0.4261 * * * \\
(.0956)\end{array}$ & $\begin{array}{c}-0.3119 * * * \\
(0.1038)\end{array}$ & $\begin{array}{r}-0.0831 \\
(.0611)\end{array}$ \\
\hline ACFTA_2 & $\begin{array}{c}-0.6064 * * * \\
(0.0809) \\
\end{array}$ & $\begin{array}{c}-0.4762 * * * \\
(0.0951)\end{array}$ & $\begin{array}{c}-0.1485^{* *} \\
(0.0555)\end{array}$ \\
\hline CONSTANT & $\begin{array}{c}-23.7279 * * * \\
(0.5868) \\
\end{array}$ & $\begin{array}{c}47.326 \\
(9.6698)\end{array}$ & $\begin{array}{c}20.6322^{* * *} \\
(1.2738)\end{array}$ \\
\hline $\mathrm{R}$ - squared value & 0.7027 & 0.7715 & 0.6399 \\
\hline
\end{tabular}

For the explanatory variables POP_EXP and POP_IMP, both variables are statistically significant at the $1 \%$ level of confidence. $\mathrm{s}$. When POP_IMP increases by $1 \%$, it will reduce about $3.63 \%$ of the import trade value [12]. This shows that the effect of domestic production and consumption is greater than the economies of scale, and countries with large populations tend to produce and consume goods domestically and are less dependent on international commerce.

The population factor in importing countries can help to explain the reasons why Vietnam in particular and ASEAN in general have difficulties in exporting goods to China. The author of the thesis stated that China has a comparative advantage in labor and natural resources, plus China's production capacity can produce and consume goods domestically. Negatively affecting the competitiveness of key ASEAN products that are often exported to China.

The variable DISTW (geographic distance between countries) is negative and statistically significant at $1 \%$ level of confidence. This is also consistent with the hypothesis of gravity model of trade on the impact of geographical distance on trade. The greater the 
geographical distance between the two countries, the higher the cost of trade between the countries, leading to trade restrictions between the two countries. The variables BORDER (country borders) and LANGUAGE (common languages) are statistically significant at the $1 \%$ level of confidence and are positive signs showing that countries sharing the same border and language tend to exchange. trade with each other. In ACFTA, these explanatory variables contribute to the interpretation of the value of imports between China and the countries of Vietnam, Malaysia and Singapore [13, 14].

For FTA dummy variables, with the exception of AANZFTA and AIFTA, which are not statistically significant, the impact of these variables on ASEAN in general and Vietnam in particular is not significant, the remaining FTA variables are significant. Statistical significance. Specifically, the explanatory variable ACFTA is negative. This shows that ACFTA has a negative impact on the import trade value of ACFTA's members. Within ACFTA, the value of ASEAN imports from China increased from 122.33 billion USD in 2005 to 569.61 billion USD in 2018 [15]. In contrast, China's import value from ASEAN only increased from 74.99 billion USD in 2005 to USD 269.09 billion USD in 2018. Thus, there was a large trade deficit between ASEAN and China in the period 2005 - 2018. In addition, the share of value of imported goods from China of ASEAN has increased significantly from $12.91 \%$ in 2010 to $20.51 \%$ in 2018 , while the percentage of Chinese imports from ASEAN only increased from $11.04 \%$ in 2010 to $12.6 \%$ in 2018 [16].

In addition, the variable ACFTA_2is statistically significant and has a negative sign, this result indicates the negative trade diversion effect of ACFTA for its members. The presence of negative trade diversion effect of ACFTA indicates that the increase in the import value of ACFTA's members was at the expense of the members' import value from other countries outside ACFTA. This is in line with the fact that: Although ASEAN countries actively sought new import partners outside China during 2001 - 2018, the value of ASEAN's imports of Chinese goods increased significantly during 2001 - 2018. Vietnam's import trade value within ACFTA is not different from the aforementioned general trend.

\section{Concluding remarks}

The authors of the paper used the gravity model of trade to analyze the import and export value of ACFTA members between 2001 and 2018. Based on the results of the tests, the author of the topic identified the FEM as the best estimation method out of the three estimation methods in the paper.

Based on the estimation results from the gravity model of trade, the authors conclude that: ACFTA created positive trade creation effect and positive trade diversion on trade of exported goods of ACFTA's members; ACFTA did contribute to promoting both intra regional and extra - regional tradevalue of Vietnam and other members of ACFTA. At the same time, within the scope of the paper, ACFTA's trade creation effect is quite large compared to other FTAs, showing that, for ASEAN and Vietnam, China is increasingly becoming an important trading partner. From the aforementioned estimation results, it can be concluded that ACFTA has a positive impact on economic integration through merchandise export trade for ACFTA and Vietnam members.

In contrast to exports, the estimation results show that ACFTA has a negative trade diversion effect on import value of ASEAN members within ACFTA, including Vietnam. The estimation results are also consistent with the actual situation of imported goods trade between ASEAN - China in general and Vietnam - China in particular: There is a siginificantly largetrade deficitin terms of imported goods of Chinaand ASEAN. Furthermore, the trade deficit between ASEAN and Chinahas been increasingsince 2010. In addition, the value of imports of ASEAN and Vietnam from China is accompanied by a 
decrease in the value of imports from other countries, which shows that Vietnam and ASEAN are becoming more dependent on China in terms of import. This may adversely affect the economic integration process of Vietnam and when trade import partners tend to be gradually restricted.

\section{References}

1. D. Ushakov, E3S Web of Conferences 175, 13038 (2020)

2. Hung Tran Van et al, E3S Web of Conferences 175, 13034 (2020)

3. H. Mai, H. Van, The EUrASEANs: Journal on Global Socio-Economic Dynamics 5(18), 23-35 (2019)

4. V. Thanh, Thu International economic relationship (Hanoi, 2012)

5. B. Balassa, The Theory of Economic Integration: An Introduction (LSU, Manila, 1960)

6. T.H. Ai, The EUrASEANs: Journal on Global Socio-Economic Dynamics 4(5), 47-58 (2017)

7. D.N. Tien, Impact of ASEAN - Korea free trade area to Vietnam Tạp chí khoa 27, 219$231(2011)$

8. S. Yang, M. Zarzoso, China Economics Review 29 (2014)

9. A. Privara, M. Privarova, Sustainability 11, 5586 (2019)

10. M. Brahmbhatt, Measuring Global Economic Integration: A Review of the Literature and Recent Evidence (World Bank, 1998)

11. Y. Heo, N.K. Doanh, International Area Review 12 (2009)

12. K. Kepaptsoglou, M. Karlaftis, D. Tsamboulas, The Open Economics Journal 03 (2010)

13. K.E. Flick, K.M. Kemburi, ASEAN - China Free Trade Area: Challenges, opportunities and the road ahead (RSIS Monograph, 2011)

14. N. Salidjanova, I. Koch - Weser, China's Economic ties with ASEAN: A country - bycountry analysis (US - China Economic and Security Review Commission Staff Research Report, 2015)

15. A. Privara, Transnational Marketing Journal 7(1), 59-72 (2019)

16. A. Př́ivara, E. Rievajová, M.M. Yüceşahin, Migration Letters 16(4), 585-594 (2019) 